\title{
p38 Mitogen-activated protein kinase regulates IL-8 expression in human pulmonary vascular endothelial cells
}

\author{
S. Hashimoto, K. Matsumoto, Y. Gon, S. Maruoka, I. Takeshita, S. Hayashi, \\ T. Koura, K. Kujime, T. Horie
}

p38 Mitogen-activated protein kinase regulates IL-8 expression in human pulmonary vascular endothelial cells. S. Hashimoto, K. Matsumoto, Y. Gon, S. Maruoka, I. Takeshita, S. Hayashi, T. Koura, K. Kujime, T. Horie. (C) ERS Journals Ltd 1999.

ABSTRACT: The aim of this study was to examine the role of p38 mitogen-activated protein (MAP) kinase in interleukin (IL)-8 expression in tumour necrosis factor (TNF)- $\alpha$ - and IL-1 $\alpha$-stimulated human pulmonary vascular endothelial cells.

To this end, the phosphorylation and activation of p38 MAP kinase and the effect of SB 203580, a specific inhibitor of p38 MAP kinase activity, on p38 MAP kinase activity and IL-8 expression in TNF- $\alpha$ - and IL-1 $\alpha$-stimulated human pulmonary vascular endothelial cells were examined.

TNF- $\alpha$ - and IL-1 $\alpha$ - induced phosphorylation and activation of p38 MAP kinase and IL-8 expression in human pulmonary endothelial cells. Inhibition of TNF- $\alpha$ - and IL-1 $\alpha$-induced p38 MAP kinase activity by SB 203580 inhibited TNF- $\alpha$ - and IL-1 $\alpha$ induced IL-8 protein production as well as IL-8 messenger ribonucleic acid (mRNA) expression, indicating that SB 203580 was effective at the transcriptional level.

These results indicate that $\mathrm{p38}$ mitogen-activated protein kinase plays an important role in the tumour necrosis factor- $\alpha$ - and interleukin- $1 \alpha$-activated signalling pathway which regulates interleukin-8 expression in human pulmonary vascular endothelial cells.

Eur Respir J 1999; 13: 1357-1364.
First Dept of Internal Medicine, Nihon University School of Medicine, Tokyo, Japan.

Correspondence: S. Hashimoto

First Dept of Internal Medicine

Nihon University School of Medicine

30-1 Oyaguchikamimachi

Itabashi-Ku

Tokyo $173-8610$

Japan

Fax: 81339722893

Keywords: Acute lung injury interleukin-8

p38 MAP kinase

pulmonary vascular endothelium

Received: November 301998

Accepted after revision February 81999
Adult respiratory distress syndrome (ARDS), a form of acute lung injury that is characterized by increased vascular permeability leading to pulmonary oedema and acute respiratory failure, is observed in severe insults such as septicaemia [1-4]. The pathogenesis of ARDS is complex and involves multiple inflammatory cells and mediators [1-4]. Neutrophils have been suggested to play an important role in the production of acute lung injury. The extravasation and accumulation of neutrophils at the sites of injury depend upon adhesion to and migration through endothelial linings [1]. Interleukin (IL)-8, which displays chemotactic activity for neutrophils, participates in this process through the recruitment of neutrophils [5]. It is well known that vascular endothelial cells produce IL-8 in response to tumour necrosis factor (TNF)- $\alpha$ and IL-1 $[6,7]$; therefore, it is important to clarify the mechanism of production of IL- 8 by TNF- $\alpha$ - and IL-1-stimulated vascular endothelial cells.

The mitogen-activated protein (MAP) kinases are important mediators of signal transduction from the cell membrane to the nucleus. Several subgroups of mammalian MAP kinases have been characterized from a molecular standpoint: extracellular signal-regulated kinase (ERK), cJun amino-terminal kinase (JNK) and p38 MAP kinase [8]. p38 MAP kinase, which is the mammalian homologue of the high osmolarity glycerol response (HOG1) protein of Saccharomyces cerevisiae [9-11], is activated in various cells by proinflammatory cytokines, environmental stresses, deoxyribonucleic acid (DNA)-damaging agents and haematopoietic growth factor [9-19]; however, little is known about the role of p38 MAP kinase in proinflammatory cytokine-induced cytokine expression in human pulmonary vascular endothelial cells. As mentioned above, IL-8 produced in pulmonary vascular endothelial cells plays an important role in the production of acute lung injury; therefore, elucidation of the signal transduction pathway involved in IL-8 expression and regulation of its expression in human pulmonary vascular endothelial cells are thought to be an important strategy for the treatment of acute lung injury.

In the present study, the role of 338 MAP kinase in the induction of IL-8 expression in human pulmonary artery endothelial cells (HPAECs) was examined in order to clarify the signal transduction pathway utilized in the expression of IL-8 in human pulmonary vascular endothelial cells.

\section{Materials and methods}

\section{Reagents}

Human recombinant IL- $1 \alpha$ and TNF- $\alpha$ were kindly provided by Ohtsuka Pharmaceutical Co. Ltd. (Tokushima, Japan) and Dainippon Pharmaceutical Co. Ltd. (Osaka, Japan), respectively. The pyridinyl imidazole SB 203580, a specific inhibitor of p38 MAP kinase activity [20], was kindly provided by SmithKline Beecham and was dissolved in dimethyl sulphoxide. The final concentration of dimethyl sulphoxide used in the experiments was $0.01 \%$. This had on effect no the results. 


\section{Cell culture}

Normal HPAECs were obtained from Clonetics (San Diego, CA, USA). The cells $\left(1 \times 10^{4}\right.$ cells $\left.\cdot \mathrm{mL}^{-1}\right)$ were placed into 24-well flat bottom tissue culture plates (Corning, Corning, NY, USA) for determination of cytokine production, and tissue culture dishes (Falcon 1007; Falcon Oxnard, CA, USA) for Western and Northern (Falcon 1005) blot analysis using vascular endothelial growth medium (EGM-2; Clonetics) containing $0.2 \%$ foetal bovine serum (FBS), 1\% gentamycin-amphotericin B, epidermal growth factor (EGF), insulin-like growth factor (IGF), fibroblast growth factor (FGF), vascular endothelial growth factor (VEGF), ascorbic acid, heparin and hydrocortisone. Cells were incubated in a humidifed $5 \% \mathrm{CO}_{2}$ atmosphere at $37^{\circ} \mathrm{C}$ until subconfluence and the medium changed.

\section{Study design}

In order to examine the effect of proinflammatory cytokines on threonine- and tyrosine-phosphorylation of p38 MAP kinase in HPAECs, cells that had been pre-incubated with EGM-2 without FBS, EGF, FGF, IGF, VEGF, ascorbic acid and hydrocortisone (growth factor-free medium) for $16 \mathrm{~h}$ were stimulated with various concentrations of either TNF- $\alpha$ or IL- $1 \alpha$ (both $100 \mathrm{ng} \cdot \mathrm{mL}^{-1}$ ) and incubated for the desired times. To determine the effect of SB 203580 on TNF- $\alpha$ - and IL- $1 \alpha$-induced p38 MAP kinase activation, growth factor- and serum-starved HPAECs that had been preincubated with or without SB 203580 (10 $\mu \mathrm{M})$ for $1 \mathrm{~h}$ were stimulated with either TNF- $\alpha$ or IL- $1 \alpha$ (both $100 \mathrm{ng} \cdot \mathrm{mL}^{-1}$ ) and incubated for $10 \mathrm{~min}$. In order to examine proinflammatory cytokine-induced IL-8 expression in HPAECs and the effect of SB 203580 on this expression, growth factor- and serum-starved HPAECs that had been preincubated with or without SB $203580(10 \mu \mathrm{m})$ for $1 \mathrm{~h}$ were stimulated with either TNF- $\alpha$ or IL-1 $\alpha$ (both $100 \mathrm{ng} \cdot \mathrm{mL}^{-1}$ ) and incubated for the desired times in a humidified $5 \% \mathrm{CO}_{2}$ atmosphere at $37^{\circ} \mathrm{C}$. After $24 \mathrm{~h}$ of culture, the culture supernatants for determination of IL8 were harvested, centrifuged (800 g, $10 \mathrm{~min}$ ) and the supernatants retained, filtered through a Millipore filter ( $0.45 \mu \mathrm{m}$ pore size; Millipore, Bedford, MA, USA) and stored at $-80^{\circ} \mathrm{C}$ until assay. The cells for analysis of IL-8 messenger ribonucleic acid (mRNA) expression were collected after $6 \mathrm{~h}$ culture and stored at $80^{\circ} \mathrm{C}$ until analysis.

\section{Measurement of interleukin-8}

The concentrations of IL- 8 in the HPAEC culture supernatants were measured using commercially available enzyme-linked immunosorbent assay (ELISA) kits (Amersham International, Aylesbury, UK). The ELISA was performed according to the manufacturer's instructions. All samples were assayed in duplicate. The minimum detectable concentration of IL- 8 was $10 \mathrm{pg} \cdot \mathrm{mL}^{-1}$. The intra- and interassay reproducibility had coefficients of variance of $4.4-4.7 \%$ and $5.2-8.1 \%$, respectively.

Western blot analysis of threonine- and tyrosine-phosphorylation of p38 mitogen-activated protein kinase

The threonine- and tyrosine-phosphorylation of p38 MAP kinase was analysed by a commercially available kit (PhosphoPlus ${ }^{\text {TM }}$ p38 MAPK Antibody Kit; New England
Biolabs, Inc., Beverly, MA, USA). Analysis of threonineand tyrosine-phosphorylation of p38 MAP kinase was performed according to the manufacturer's instructions. Briefly, the cells that had been washed with cold tris (hydroxymethyl)aminomethane (Tris)-buffered saline were lysed in sodium dodecylsulphate (SDS) buffer $(62.5 \mathrm{mM}$ Tris- $\mathrm{HCl} \mathrm{pH} 6.8,2 \% \mathrm{w} / \mathrm{v}$ SDS, 10\% glycerol, $50 \mathrm{mM}$ dithiothreitol (DTT), $0.1 \% \mathrm{w} / \mathrm{v}$ bromphenol blue) for $15 \mathrm{~min}$ on ice and then sonicated for $2 \mathrm{~s}$ to shear DNA. The samples were heated in a boiling water bath for $5 \mathrm{~min}$ to fully denature proteins prior to electrophoresis and then centrifuged at $12,000 \times g$ for $5 \mathrm{~min}$ to remove insoluble debris. After separating proteins from the cell lysate by means of $15 \%$ SDS-polyacrylamide gel electrophoresis, the proteins (from lysate containing $10 \mu \mathrm{g}$ protein) were electrophoretically transferred to a nitrocellulose membrane and the membrane washed with $0.1 \%$ Tween 20 in Tris-buffered saline (washing buffer). In order to block nonspecific protein binding, the membrane was incubated with $0.1 \%$ Tween 20 in Tris-buffered saline containing $5 \% \mathrm{w} / \mathrm{v}$ nonfat powdered milk for $3 \mathrm{~h}$ at room temperature. It was then incubated with a specific antibody directed against the phosphorylated threonine and tyrosine of p38 MAP kinase (affinity-purified rabbit polyclonal immunoglobulin $(\mathrm{Ig}) \mathrm{G})$ at $1: 1,000$ dilution in $0.1 \%$ Tween 20 in Tris-buffered saline containing $5 \%$ bovine serum albumin overnight at $4 \mathrm{C}$ with gentle shaking. After three washes with washing buffer, the membrane was incubated with the horseradish peroxidase (HRP)-conjugated antirabbit antibody $(1: 2,000)$ and HRP-conjugated antibiotin antibody $(1: 1,000)$ for $1 \mathrm{~h}$ at room temperature with gentle shaking and then washed three times with washing buffer. It was then incubated with enhanced chemiluminescence (ECL) solution (LumiGLO; New England Biolabs, Inc.) for 1 min at room temperature and exposed against Kodak XAR (Tokyo, Japan) film to detect biotin-labelled proteins. Blots were stripped and reprobed using a phosphorylation-state independent p38 MAP kinase-specific antibody to determine total p38 MAP kinase levels (affinity-purified rabbit polyclonal IgG).

\section{p38 Mitogen-activated protein kinase assay}

The activity of p38 MAP kinase was analysed using a commercially available kit (p38 MAP Kinase Assay Kit; New England Biolabs, Inc.). The kit employs two different antibodies, anti-p38 MAP kinase antibody, which is specific for p38 MAP kinase and does not cross-react with ERK1/2 or JNK, and antiphospho-specific activating transcription factor-2 (ATF-2) antibody for detecting p38 MAP kinase-induced phosphorylation of ATF-2. Analysis of the activity of p38 MAP kinase was performed according to the manufacturer's instructions. Briefly, the cells that had been washed with ice-cold phosphate-buffered saline (PBS) were lysed in $1.0 \mathrm{~mL}$ ice-cold lysis buffer $(20 \mathrm{mM}$ Tris $\mathrm{pH}$ $7.4,150 \mathrm{mM} \mathrm{NaCl}, 1 \mathrm{mM}$ ethylenediamine tetraacetic acid (EDTA), $1 \mathrm{mM}$ ethyleneglycol-bis-( $\beta$-aminoethylether)-N, N,N', N'-tetraacetic acid (EGTA), 1\% Triton X-100, 2.5 $\mathrm{mM}$ sodium pyrophosphate, $1 \mathrm{mM} \beta$-glycerol phosphate, 1 $\mathrm{mM} \mathrm{Na} \mathrm{VO}_{4}, 1 \mu \mathrm{g} \cdot \mathrm{mL}^{-1}$ leupeptin) plus $1 \mathrm{mM}$ phenylmethylsulphonyl fluoride (PMSF) in the six well plate for 5 min on ice. After sonication, the cell lysate was microcentrifuged for $10 \mathrm{~min}$ at $4^{\circ} \mathrm{C}$. The cell lysate containing 
$100 \mu \mathrm{g}$ protein, was incubated with anti-p38 MAP kinase antibody (1:1,000 dilution) overnight at $4{ }^{\circ} \mathrm{C}$ with gentle shaking to selectively immunoprecipitate p38 MAP kinase from cell lysates. The resulting immunoprecipitate was then mixed with protein A-Sepharose beads. After microcentrifugation, the pellet was washed twice with lysis buffer and then twice with kinase buffer $(25 \mathrm{mM}$ Tris $\mathrm{pH} 7.5,5$ $\mathrm{mM} \beta$-glycerol phosphate, $2 \mathrm{mM}$ DTT, $0.1 \mathrm{mM} \mathrm{Na} \mathrm{VO}_{4}$, $10 \mathrm{mM} \mathrm{MgC1} 2$ ). The pellet was suspended in $50 \mu \mathrm{L}$ kinase buffer with $100 \mu \mathrm{M}$ adenosine triphosphate (ATP) and 2 $\mu \mathrm{g}$ ATF-2 fusion protein and then incubated for $30 \mathrm{~min}$ at $30^{\circ} \mathrm{C}$. This pellet was mixed with a sample buffer consisting of $62.5 \mathrm{mM}$ Tris base, $10 \%$ glycerol, $50 \mathrm{mM}$ DTT and $2 \%$ SDS, and then heated in a boiling water bath for 5 min to fully denature the proteins prior to electrophoresis. Equal amounts of protein ( $5 \mu \mathrm{g}$ per lane) were separated in a $15 \%$ SDS gel and transferred to a polyvinylidene difluoride sheet (Millipore) by means of electroelution using a constant current of $200 \mathrm{~mA}$ for $90 \mathrm{~min}$ at room temperature. After blocking overnight with at $4{ }^{\circ} \mathrm{C} 0.1 \%$ Tween 20 in PBS (T-PBS) containing 5\% (w/v) skimmed milk, the sheet was incubated with antiphospho-specific ATF-2 antibody (1:1,000 dilution) overnight at $4^{\circ} \mathrm{C}$. The sheet was then washed three times with T-PBS and incubated with HRP-conjugated antirabbit antibody $(1: 2,000)$ and HRPconjugated antibiotin antibody $(1: 2,000)$ for $1 \mathrm{~h}$ at room temperature. After washing with T-PBS three times, the sheet was incubated with $10 \mathrm{~mL}$ ECL solution for $1 \mathrm{~min}$ according to the manufacturer's instructions, and exposed against Fuji medical radiography film (Fuji Photo Film Co., Tokyo, Japan) for $1 \mathrm{~min}$.

\section{Extracellular signal-regulated kinase assay}

The activity of ERK was analysed using commercially available kits (MAP Kinase Assay kit; New England Biolabs, Inc.). The kit employs two different antibodies, antiphospho-specific p42/p44 MAP kinase antibody, which is specific for active p42/p44 MAP kinase and does not cross-react with p38 MAP kinase or JNK, and antiphospho-specific Elk-1 antibody for detecting p42/p44 MAP kinase-induced phosphorylation of Elk-1. Analysis of the activity of ERK was performed according to the manufacture's instructions.

\section{c-Jun amino-terminal kinase assay}

The activity of JNK was analysed using commercially available kits (stress-activated protein kinase (SPAK)/JNK Assay kits, New England Biolabs, Inc.). The kits employ an amino-terminal c-Jun fusion protein bound to sepharose beads to selectively remove JNK from the cell lysates, after which the kinase reaction is carried out in the presence of unlabelled ATP. The c-Jun phosphorylation was selectively measured using phospho-specific c-Jun antibody to determine JNK-induced phosphorylation of c-Jun. Analysis of the activity of JNK was performed according to the manufacturer's instructions.

\section{Northern blot analysis}

Total ribonucleic acid (RNA) was prepared by means of an RNA extraction kit (RNA zol B ${ }^{\mathrm{TM}}$; Cinna Scientific, Friedswods, TX, USA) using acid guanidine thiocyanate- phenol-choloroform extraction methods. Total RNA (10 $\mu \mathrm{g}$ ) was denatured in a solution containing $2.2 \mathrm{M}$ formaldehyde, and electrophoresed in a $1 \%$ agarose gel containing formaldehyde [21]. It was then capillary-transferred onto a nylon membrane (Hybond N, Amersham). The membrane was prehybridized with rapid hybribuffer (Amersham) and then hybridized with $\left[{ }^{32} \mathrm{P}\right]$ - labelled probes for $2 \mathrm{~h}$ at $65^{\circ} \mathrm{C}$. The probes used in this study were the Providencia stuartii (Pst) $\mathrm{I}-$ Pst $\mathrm{I}$ fragments of $\beta$-actin complementary deoxyribonucleic acid (cDNA) and fulllength IL-8 cDNA [22], which were kindly provided by K. Matsushima (Tokyo University School of Medicine, Dept of Hygiene). After hybridization, the membrane was washed with $0.1 \%$ standard sodium citrate containing $0.1 \%$ SDS and then autoradiographed against Kodak $\mathrm{XAR}$ film at $-70^{\circ} \mathrm{C}$.

\section{Statistical analysis}

Statistical significance was analysed using analysis of variance (ANOVA). A p-value $<0.05$ was considered significant.

\section{Results}

Tumour necrosis factor- $\alpha$ and interleukin-1 $\alpha$ induce interleukin-8 production

Firstly, the dose-dependent induction of IL- 8 production by HPAECs was examined. To this end, the culture supernatants from HPAECs stimulated with various concentrations of TNF- $\alpha$ or IL- $1 \alpha$ were harvested after $24 \mathrm{~h}$ of culture (fig. 1). The concentrations of IL-8 in culture supernatants from TNF- $\alpha$-stimulated cultures increased in a dose-dependent manner. Similarly, the concentrations of IL-8 in the culture supernatants from IL- $1 \alpha$-stimulated culture increased in a dose-dependent manner.
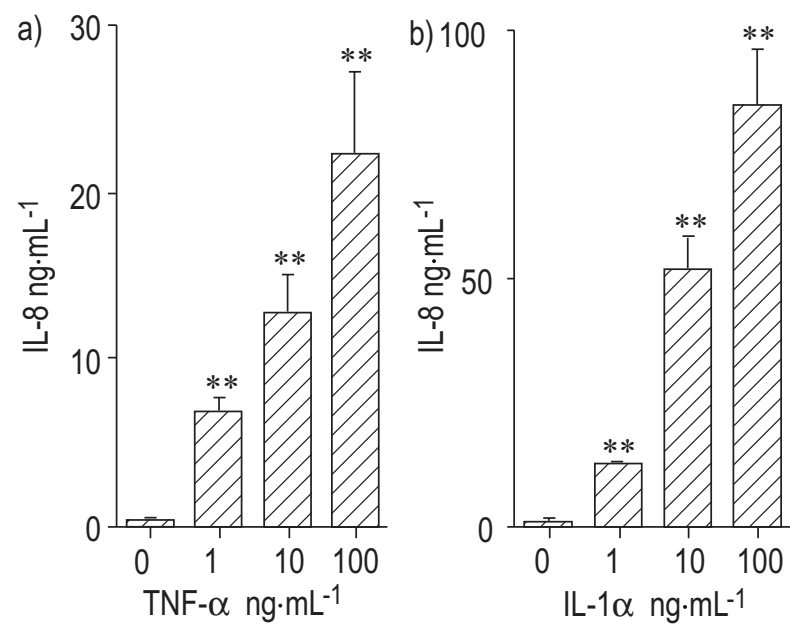

Fig. 1. - Induction of interleukin (IL)- 8 production by: a) tumour necrosis factor- $\alpha$ (TNF- $\alpha$ ); and b) IL-1 $\alpha$. Human pulmonary artery endothelial cells (HPAECs) were incubated for $24 \mathrm{~h}$ in medium containing various concentrations of either TNF- $\alpha$ or IL- $1 \alpha$, and the concentrations of IL- 8 in the culture supernatants determined after $24 \mathrm{~h}$ of culture, as described in Materials and methods. The results are expressed as mean \pm SD of five different experiments. $* *: \mathrm{p}<0.01$ versus HPAECs cultured in medium alone. 
Tumour necrosis factor- $\alpha$ and interleukin- $1 \alpha$ cause threonine- and tyrosine-phosphorylation of p38 mitogenactivated protein kinase

To determine whether or not TNF- $\alpha$ and IL- $1 \alpha$ induce threonine- and tyrosine-phosphorylation of p38 MAP kinase, HPAECs were stimulated for the desired times and p38 MAP kinase was immunoblotted. Immunoblot analysis of HPAEC lysates using a specific antibody directed against the phosphorylated threonine and tyrosine of p38 MAP kinase showed that stimulation of the cells with TNF- $\alpha$ caused an increase in threonine- and tyrosinephosphorylation of p38 MAP kinase in a dose-dependent manner (fig. 2a). In order to determine the time-course of phosphorylation of p38 MAP kinase, HPAECs were stimulated with $100 \mathrm{ng} \cdot \mathrm{mL}^{-1}$ TNF- $\alpha$ for $0-60 \mathrm{~min}$. The amounts of phosphorylated threonine and tyrosine of p38 MAP kinase were increased at $5 \mathrm{~min}$, these levels being sustained at 10 and $15 \mathrm{~min}$; thereafter they returned to near-basal levels, at $30 \mathrm{~min}$, indicating that threonine- and tyrosine-phosphorylation of p38 MAP kinase was transient (fig. 2b). IL-1 $\alpha$-induced threonine- and tyrosinephosphorylation of p38 MAP kinase was also increased in a dose-dependent manner (fig. 3a). The amounts of IL$1 \alpha$-induced threonine- and tyrosine-phosphorylation of p38 MAP kinase were increased at 5 min, these levels being sustained between 10 and $30 \mathrm{~min}$; thereafter they returned to near-basal levels, at $60 \mathrm{~min}$ (fig. 3b). Equal amounts of 38 MAP kinase protein were immunoblotted using p38 MAP kinase-specific antibody regardless of the dose of TNF- $\alpha$ and IL- $1 \alpha$ and the duration of culture, indicating that TNF- $\alpha$ and IL- $1 \alpha$ stimulation-induced increases in threonine- and tyrosine-phosphorylation of p38 MAP kinase occurred in the absence of changes in p38 MAP kinase protein levels. When HPAECs were cultured in growth factor-free medium in the absence of TNF- $\alpha$ and IL- $1 \alpha$, increases in the amounts of threonineand tyrosine-phosphorylation of p38 MAP kinase were not observed at any point during culture (data not shown).

Tumour necrosis factor-a and interleukin-1a activate p38 mitogen-activated protein kinase

Activation of p38 MAP kinase is mediated by dual phosphorylation of the threonine and tyrosine residues of p38 MAP kinase [12]. The increases in threonine- and tyrosine-phosphorylation of $\mathrm{p} 38$ MAP kinase in TNF- $\alpha-$ and IL- $1 \alpha$-stimulated cells shown in figures 2 and 3 reflect the activation state of p38 MAP kinase. In addition to analysis of threonine- and tyrosine-phosphorylation of p38 MAP kinase, the effect of SB 203580, a specific inhibitor of $\mathrm{p} 38$ MAP kinase activity, on TNF- $\alpha$ - and IL$1 \alpha$-induced p38 MAP kinase activity was also examined. p38 MAP kinase activity was analysed by means of a specific immunoprecipitation with anti-p38 MAP kinase antibody followed by an in vitro kinase assay of its substrate, ATF-2. As shown in figure 4, TNF- $\alpha$ and IL- $1 \alpha$ activated p38 MAP kinase, as demonstrated by the increased phosphorylation of its substrate, ATF-2. Pretreatment of the cells with SB 203580 reduced the phosphorylation of ATF-2. To determine the specificity of the inhibitory effect of SB 203580 on p38 MAP kinase activity, the effect of SB 203580 on ERK and JNK activity in TNF- $\alpha-$ and IL- $1 \alpha$-stimulated HPAECs was also examined. TNF-
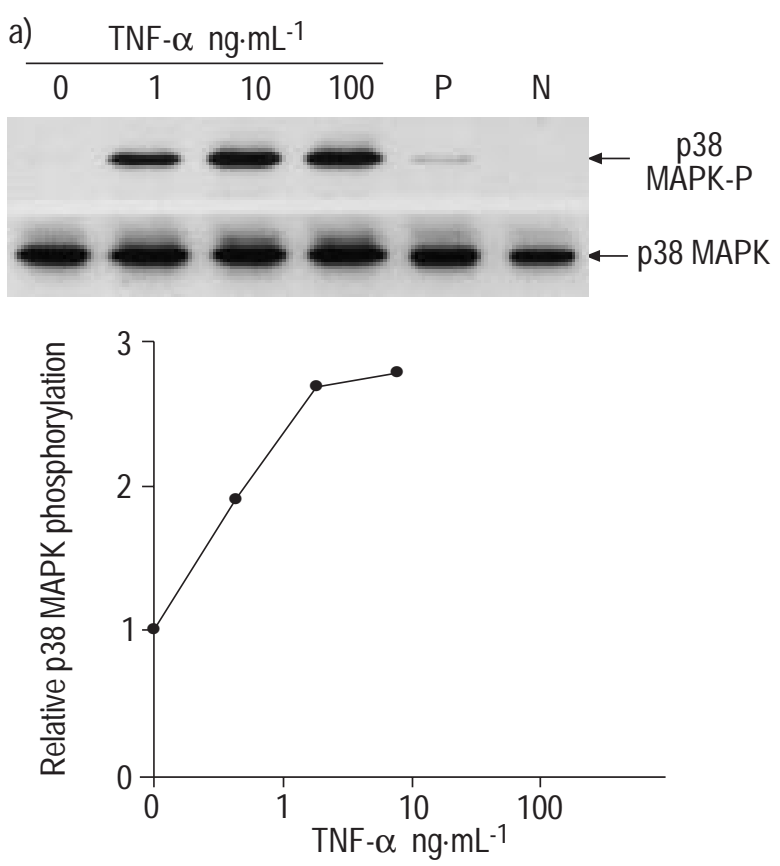

b)

b) Time $\min$
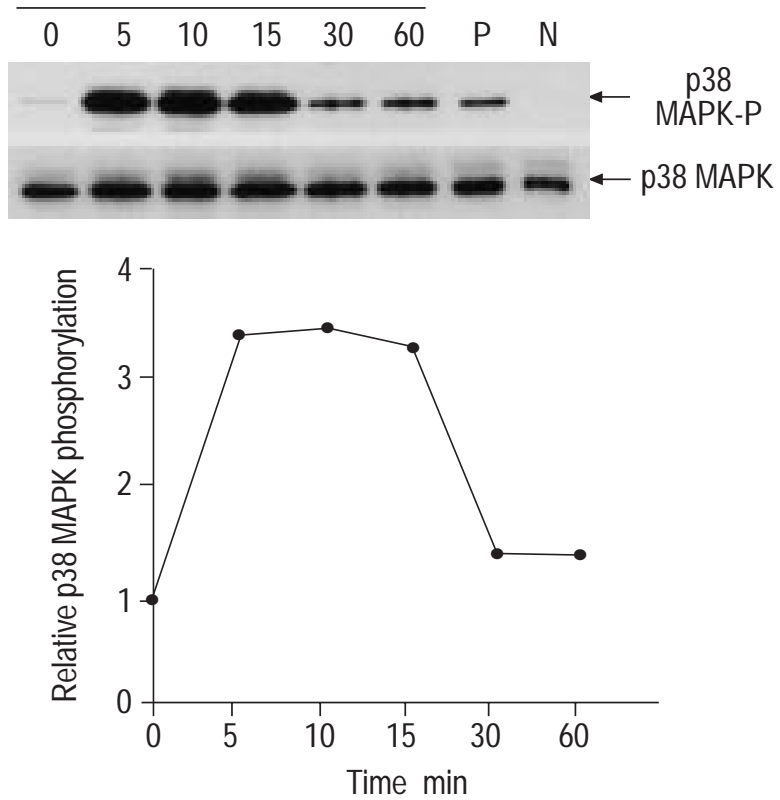

Fig. 2. - Tumour necrosis factor- $\alpha$ (TNF- $\alpha$ ) causes threonine- and tyrosine-phosphorylation of p38 mitogen-activated protein kinase (MAPK). Human pulmonary artery endothelial cells (HPAECs) were stimulated with: a) various concentrations of TNF- $\alpha$ for $5 \mathrm{~min}$; and b) $100 \mathrm{ng} \cdot \mathrm{mL}^{-1}$ TNF- $\alpha$ for $0-60 \mathrm{~min}$. The HPAEC lysates were separated in a $15 \%$ sodium dodecyl sulphate-polyacrylamide gel, transferred to nitrocellulose membranes and probed with a specific antibody directed against the phosphorylated threonine and tyrosine of p38 MAPK (p38 MAPK-P; upper blot panels). These blots were then stripped and reprobed using a p38 MAPK specific antibody to determine the amounts of p38 MAPKblotted (lower blot panels). P: positive control - protein prepared from C-6 glioma cells stimulated with anisomycin to phosphorylate the threonine and tyrosine of $\mathrm{p} 38 \mathrm{MAPK}$; N: negative control - protein prepared from C- 6 glioma cells not stimulated with anisomycin. The amount of p38 MAPK phosphorylation was quantitated using a National Institutes of Health (NIH) image analyser (National Institute of Health, Bethesda, MD, USA) and are presented as the amount of p38 MAPK phosphorylation relative to control cells treated without agonist (1.0). Three identical experiments, independently performed, gave similar results. 

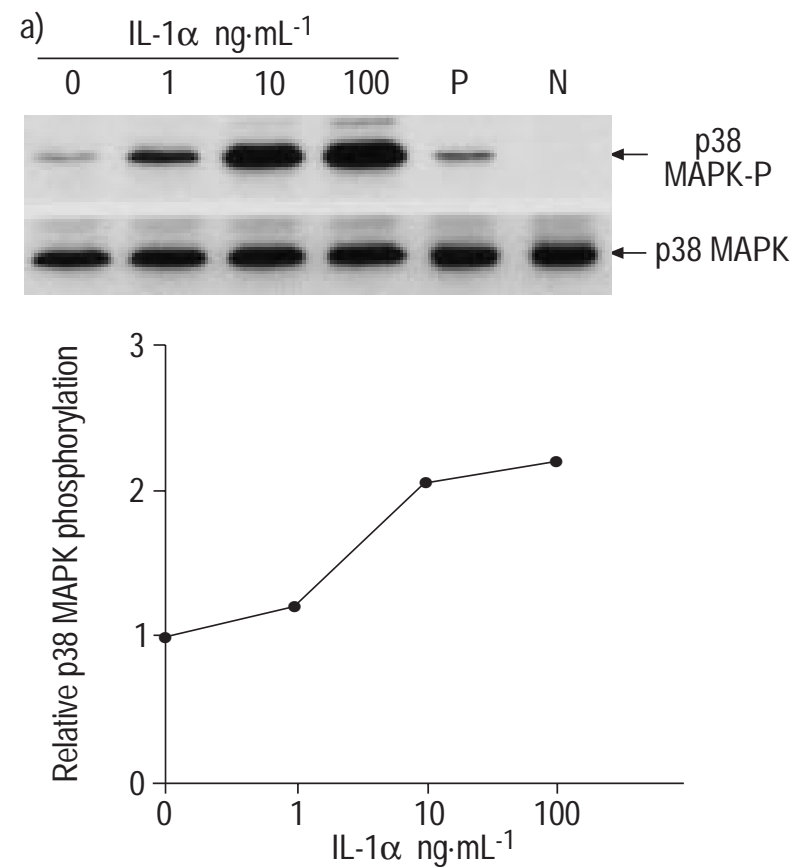

b)
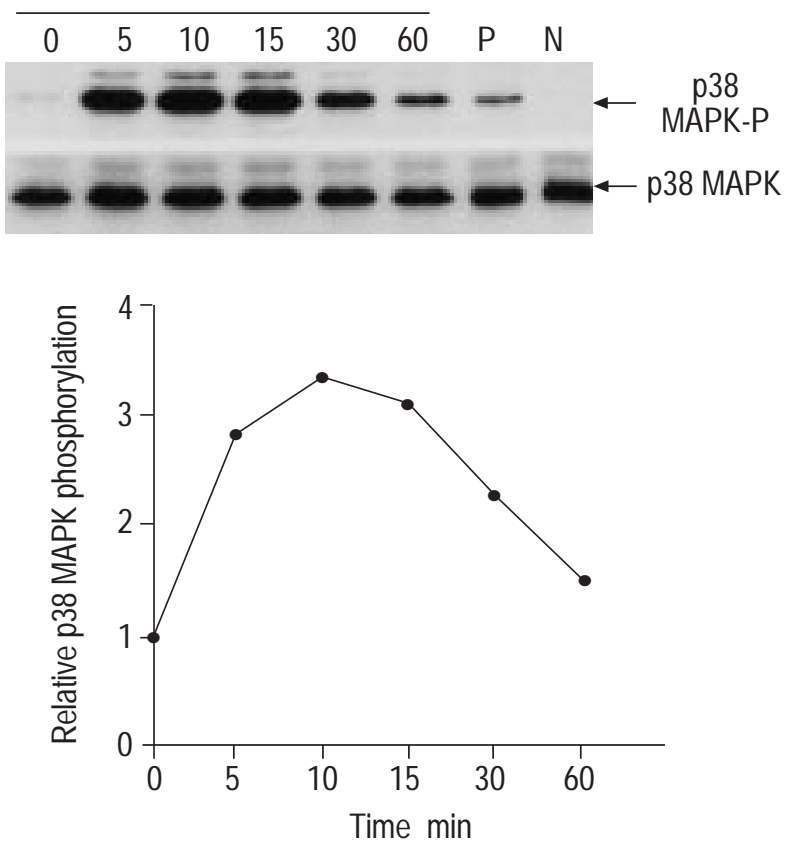

Fig. 3. - Interleukin- $1 \alpha$ (IL-1 $\alpha)$ causes threonine- and tyrosine-phosphorylation of $\mathrm{p} 38$ mitogen-activated protein kinase (MAPK). Human pulmonary artery endothelial cells (HPAECs) were stimulated with: a) various concentrations of IL- $1 \alpha$ for $5 \mathrm{~min}$; and b) $100 \mathrm{ng} \cdot \mathrm{mL}^{-1} \mathrm{IL}-1 \alpha$ for 0-60 min. The HPAEC lysates were separated in a $15 \%$ sodium dodecyl sulphate-polyacrylamide gel, transferred to nitrocellulose membranes and probed with specific antibody directed against the phosphorylated threonine and tyrosine of p38 MAPK (p38 MAPK-P; upper blot panels). These blots were then stripped and reprobed using a p38 MAPK-specific antibody to determine amounts of p38 MAPK blotted (lower blot panels). P: positive control - with phosphorylated p38 MAPK; N: negative control. The amount of p38 MAPK phosphorylation was quantitated using a National Institutes of Health (NIH) image analyser (National Institute of Health, Bethesda, MD, USA) and are presented as the amount of p38 MAPK phosphorylation relative to control cells treated without agonist (1.0). Three identical experiments, independently performed, gave similar results.

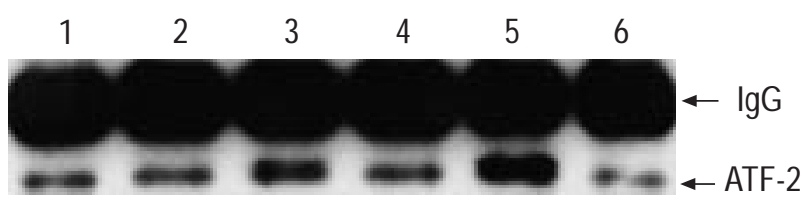

Fig. 4. - Tumour necrosis factor- $\alpha$ (TNF- $\alpha$ ) and interleukin (IL)- $1 \alpha$ activate p38 mitogen-activated protein (MAP) kinase and SB 203580 inhibits p38 MAP kinase activity. Human pulmonary artery endothelial cells (HPAECs) that had been preincubated either without (lanes 1, 3 and 5) or with SB $203580(10 \mu \mathrm{M}$; lanes 2, 4 and 6), a specific inhibitor for p38 MAP kinase activity for $1 \mathrm{~h}$ were stimulated with medium alone (lanes 1 and 2), TNF- $\alpha\left(100 \mathrm{ng} \cdot \mathrm{mL}^{-1}\right)$, (lanes 3 and 4$)$ or $\mathrm{IL}^{-1} \alpha(100$ $\mathrm{ng} \cdot \mathrm{mL}^{-1}$ ), (lanes 5 and 6 ), for $10 \mathrm{~min}$. After culture, the cell lysates were incubated with anti-p38 MAP kinase antibody to selectively immunoprecipitate p38 MAP kinase from the cell lysates and then the immunoprecipitates incubated with ATF-2 fusion protein in the presence of adenosine triphosphate which allowed immunoprecipitated active p38 MAP kinase to phosphorylate ATF-2. (The anti-p38 MAP kinase antibody (immunoglobulin (Ig) G) is activated by phosphorylation.) The proteins were separated in a $15 \%$ sodium dodecyl sulphate-polyacrylamide gel, transferred to polyinylidene difluoride membranes and probed with an anti-phosphospecific ATF-2 antibody. Three identical experiments, independently performed, gave similar results. IgG: immunoglobulin G.

$\alpha$ and IL- $1 \alpha$ activated ERK and JNK, as demonstrated by the increased phosphorylation of their substrates, Elk-1 and c-Jun, respectively; SB 203580 did not show any inhibitory effect on the phosphorylation of Elk-1 and cJun (fig. 5). These results indicate that SB 203580 specifically inhibits p38 MAP kinase activity and does not affect ERK and JNK activity in TNF- $\alpha$ - and IL- $1 \alpha$ stimulated HPAECs. In addition, PD $98059(50 \mu \mathrm{M})$ a specific inhibitor of ERK kinase (MEK-1), which is upstream of ERK, did not inhibit IL-8 production (data not shown).

SB 203580 inhibits tumour necrosis factor- $\alpha-$ and interleukin-1 $\alpha$-induced interleukin- 8 production

TNF- $\alpha$ and IL- $1 \alpha$ induced IL- 8 production and the phosphorylation and activation of p38 MAP kinase in HPAECs. These results suggest that TNF- $\alpha$ and IL- $1 \alpha$ stimulation-induced IL- 8 production might be mediated through a p38 MAP kinase-dependent pathway. To test this possibility, HPAECs that had been preincubated with or without SB 203580 were incubated with either TNF- $\alpha$ or IL- $1 \alpha$, and the concentrations of IL- 8 in the culture supernatants determined after $24 \mathrm{~h}$ of culture. As shown in figure 6 , the concentrations of IL-8 in the culture supernatants of cells incubated with TNF- $\alpha$ in the presence of SB 203580 were lower than those in the absence of SB 203580, indicating that SB 203580 inhibited TNF- $\alpha-$ induced IL-8 production. Similarly, SB 203580 inhibited IL- $1 \alpha$-induced IL- 8 production.

SB 203580 inhibits tumour necrosis factor- $\alpha-$ and interleukin-1 $\alpha$-induced interleukin- 8 messenger ribonucleic acid expression

The inhibitory effect of the specific p38 MAP kinase inhibitor on TNF- $\alpha$ - and IL- $1 \alpha$-induced IL- 8 protein production by HPAECs suggested that this action may be the result of a direct inhibitory effect on IL-8 gene expression. To test this possibility, HPAECs that had been preincubated with or without SB 203580 were incubated with either TNF- $\alpha$ or IL- $1 \alpha$ and IL-8 mRNA expression was 

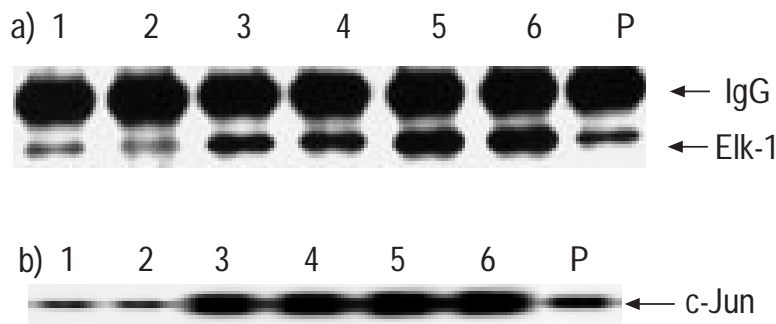

Fig. 5. - Effect of SB 203580 on tumour necrosis factor (TNF)- $\alpha$ - and interleukin (IL)- $1 \alpha$-induced extracellular signal-regulated kinase (ERK) (a) and c-Jun amino terminal kinase (JNK) activity (b). Human pulmonary artery endothelial cells (HPAECs) that had been preincubated either without (lanes 1, 3 and 5) or with SB $203580(10 \mu \mathrm{M}$; lanes 2, 4 and 6) a specific inhibitor of p38 MAP kinase activity, for $1 \mathrm{~h}$ were stimulated with medium alone (lanes 1 and 2), TNF- $\alpha\left(100 \mathrm{ng} \cdot \mathrm{mL}^{-1}\right.$; lanes 3 and 4$)$ or IL-1 $\alpha\left(100 \mathrm{ng} \cdot \mathrm{mL}^{-1}\right.$; lanes 5 and 6$)$. After culture ERK and JNK activity were determined using Elk-1 and c-Jun fusion protein as substrate, respectively, as described in Materials and methods. P: positive control - phosphorylated Elk-1 and c-Jun respectively. Three identical experiments, independently performed, gave similar results

analysed after $6 \mathrm{~h}$ of culture. As shown in figure 7, IL8 mRNA expression was upregulated when HPAECs were stimulated with TNF- $\alpha$ (lane 3) or IL-1 $\alpha$ (lane 5), and SB 203580 inhibited the TNF- $\alpha$ - or IL- $1 \alpha$-induced upregulation of IL-8 mRNA expression (lanes 4 and 6). Levels of $\beta$-actin mRNA expression did not vary significantly.

\section{Cell viability}

The total number of cells and cell viability determined by means of the trypan blue exclusion assay, which was performed after $24 \mathrm{~h}$ of culture for the determination of IL8 concentrations, and after $6 \mathrm{~h}$ of culture for the determination of IL-8 mRNA expression, did not differ with culture conditions. Figures 1,6 and 7 suggest that TNF- $\alpha-$ and IL- $1 \alpha$-induced IL- 8 expression and its inhibition by SB 203580 did not result from cell cytotoxicity.

\section{Discussion}

In the present study, the signal transduction pathway of TNF- $\alpha$ - and IL- $1 \alpha$-induced IL- 8 expression in human pulmonary vascular endothelial cells was examined. TNF$\alpha$ and IL- $1 \alpha$ induced IL- 8 expression and threonine- and tyrosine-phosphorylation and activation of p38 MAP kinase in human pulmonary vascular endothelial cells. SB 203580, a specific inhibitor of p38 MAP kinase activity, inhibited TNF- $\alpha$ - and IL- $1 \alpha$-induced IL- 8 expression in human pulmonary vascular endothelial cells. These results indicate that p38 MAP kinase plays an important role in the TNF- $\alpha$ - and IL- $1 \alpha$-activated signalling pathway which regulates IL-8 expression in human pulmonary vascular endothelial cells.

TNF- $\alpha$ and IL- $1 \alpha$ have been shown to induce the phosphorylation and activation of p38 MAP kinase in various cells $[9,10,12-14]$; however, little is known about the intracellular signal transduction pathway regulating IL- 8 expression in TNF- $\alpha$ - and IL- $1 \alpha$-stimulated human pulmonary vascular endothelial cells. In the present study, it was demonstrated that TNF- $\alpha$ and IL-1 $\alpha$ induced threonine- and tyrosine-phosphorylation and activation of p38 MAP kinase in human pulmonary vascular
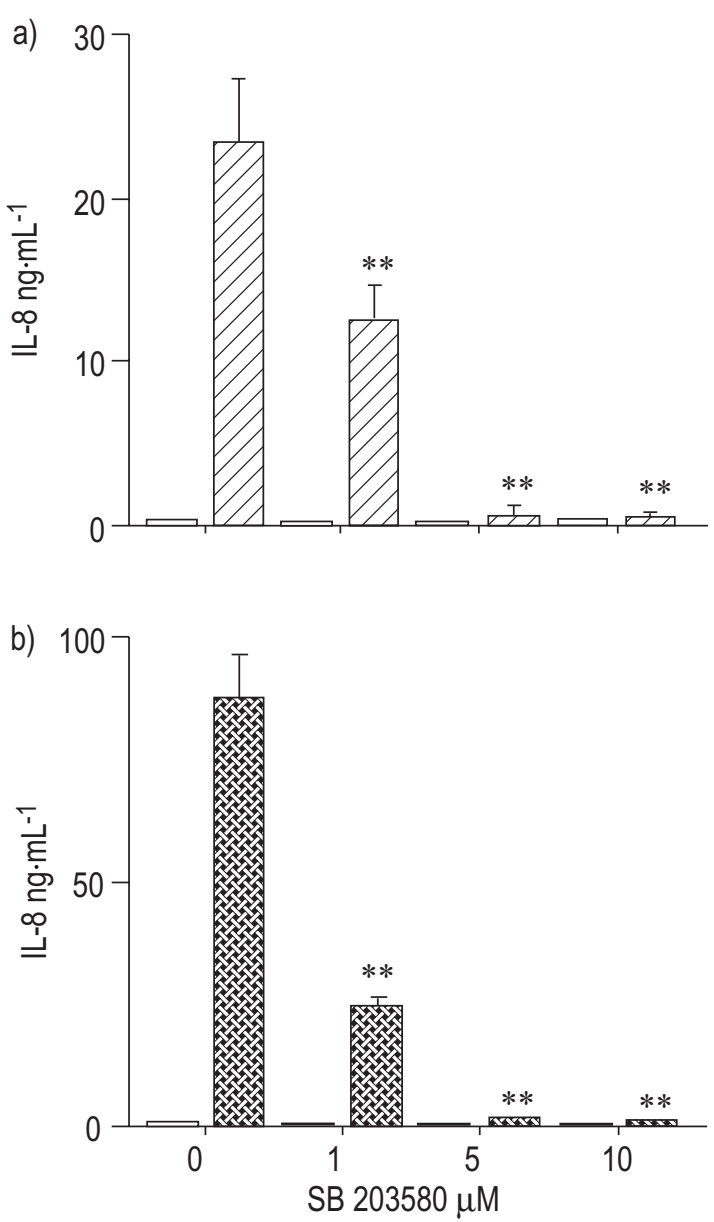

Fig. 6. - SB 203580 inhibits tumour necrosis factor (TNF)- $\alpha$ - and interleukin (IL)- $1 \alpha$-induced IL- 8 production. Human pulmonary artery endothelial cells (HPAECs) that had been preincubated with various concentrations of SB 203580 for $1 \mathrm{~h}$ were incubated with either medium alone $(\square)$, TNF- $\alpha\left(100 \mathrm{ng} \cdot \mathrm{mL}^{-1}\right)(\mathrm{a} ; \mathbb{Z})$ or IL-1 $\alpha\left(100 \mathrm{ng} \cdot \mathrm{mL}^{-1}\right)(\mathrm{b} ; \times)$ for $10 \mathrm{~min}$ and the concentrations of IL- 8 in the culture supernatants determined after $24 \mathrm{~h}$ of culture, as described in Materials and methods. The results are expressed as mean \pm SD of five different experiments. $* *$ : $\mathrm{p}<0.01$ versus on SB 203580.

endothelial cells. Other subgroups of MAP kinase, ERK and JNK, are also activated in response to TNF- $\alpha$ and IL$1 \alpha[12,23]$. Therefore, SB 203580, a specific inhibitor of p38 MAP kinase activity $[20,24]$, was used to investigate the signal transduction pathway regulating IL-8 expression in TNF- $\alpha$-, and IL- $1 \alpha$-stimulated human pulmonary vascular endothelial cells. SB 203580 completely inhibited p 38 MAP kinase activity and IL- 8 expression in the TNF- $\alpha$ - and IL- $1 \alpha$-stimulated human pulmonary vascular endothelial cells, indicating that p38 MAP kinase plays an important role in TNF- $\alpha$ - and IL- $1 \alpha$-activated signalling pathway which regulates IL-8 expression.

In order to determine the level at which SB 203580 inhibits IL-8 protein production, Northern blot analysis was performed. SB 203580 inhibited TNF- $\alpha$-induced upregulation of IL-8 mRNA expression in human pulmonary vascular endothelial cells. A similar inhibitory effect of SB 203580 was also evident in IL- $1 \alpha$-induced IL- 8 mRNA expression. These results indicate that SB 203580 might inhibit TNF- $\alpha$ - and IL- $1 \alpha$-induced IL- 8 expression at the level of transcription. 


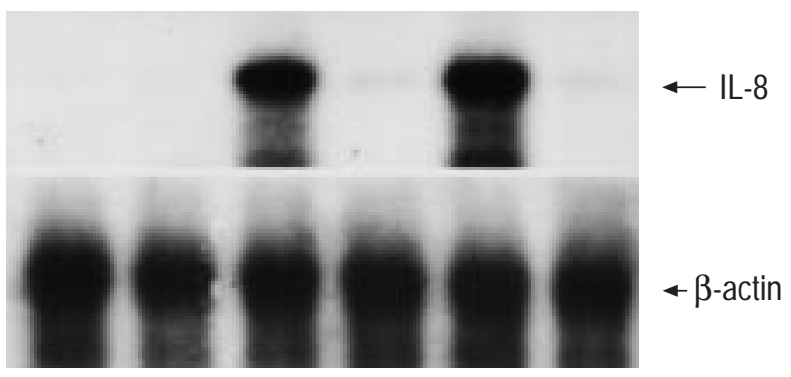

Fig. 7. - SB 203580 inhibits tumour necrosis factor (TNF)- $\alpha$ - and interleukin (IL)-1 $\alpha$ - induced IL-8 messenger ribonucleic acid (mRNA) expression. Human pulmonary artery endothelial cells (HPAECs) that had been preincubated without (lanes 1, 3 and 5) or with SB 203580 (10 $\mu \mathrm{M}$; lanes 2, 4 and 6 ) for $1 \mathrm{~h}$ were incubated with either medium alone (lanes 1 and 2), TNF- $\alpha\left(100 \mathrm{ng} \cdot \mathrm{mL}^{-1}\right.$; lanes 3 and 4$)$ or IL-1 $\alpha(100$ $\mathrm{ng} \cdot \mathrm{mL}^{-1}$; lanes 5 and 6 ) for $6 \mathrm{~h}$, and IL-8 and $\beta$-actin mRNA expression were analysed via Northern blot analysis, as described in Materials and methods. Three identical experiments, independently performed, gave similar results.

Although SB 203580 completely inhibited IL-8 expression in TNF- $\alpha$ - and IL- $1 \alpha$-stimulated human pulmonary vascular endothelial cells, a partial inhibition of IL-8 production in TNF- $\alpha$ - and IL- $1 \alpha$-stimulated human umbilical vein endothelial cells (HUVECs) has been reported [25]. Such contrasting effects of SB 203580 on IL-8 expression between human pulmonary vascular endothelial cells and HUVECs suggest that the signal transduction pathway regulating IL-8 expression may be cell type-specific.

In this study, TNF- $\alpha$ and IL- $\alpha$ were used as inducers for the examination of the signal transduction pathway involved in IL-8 expression in human pulmonary vascular endothelial cells. ARDS is frequently seen in conjunction with septicaemia caused by Gram-negative bacteria [2]. The elevation of TNF- $\alpha$ and IL-1 in ARDS and the role of these cytokines in the production of ARDS have been documented [26, 27]. Although ARDS and acute lung injury can occur in neutropenic patients [28] and a neutrophil-depleted animal model [29], several lines of study have suggested that neutrophils play an important role in the production of acute lung injury [1-4]. IL-8 exhibits a chemotactic effect on neutrophils [5]. IL-8 produced by vascular endothelial cells stimulated with TNF- $\alpha$ and IL1 has been suggested to contribute to the production of acute lung injury through recruitment of neutrophils into the site of inflammation [30]. Therefore, analysis of the intracellular signal transduction pathway regulating IL-8 expression and the inhibition of IL-8 expression in human pulmonary vascular endothelial cells is an important strategy for the treatment of acute lung injury such as ARDS. The specific inhibitor of p38 MAP kinase activity used in this study, SB 203580, was originally discovered as an inhibitor of lipopolysaccharide-induced production of IL1 and TNF- $\alpha$ in the human monocytic cell line THP-1, [20]. This drug has been thought to be useful in the treatment of inflammatory diseases [20]. In the present study, it was shown that SB 203580 inhibited IL-8 expression by human pulmonary vascular endothelial cells. Therefore, the specific inhibitor of p38 MAP kinase activity, SB 203580, may have a potential role in controlling acute lung injury through inhibiting IL- 8 production.
From the data presented here, it is concluded that tumour necrosis factor- $\alpha$ and interleukin- $1 \alpha$ induce interleukin- 8 expression in human pulmonary vascular endothelial cells through a p38 mitogen-activated protein kinase dependent pathway.

\section{References}

1. Hashimoto S, Horie T. Adult respiratory distress syndrome and adhesion molecules. In: Takishima T, ed. Basic and Clinical Aspects of Pulmonary Fibrosis. Boca Raton, CRC Press, 1994; pp. 433-443.

2. Nogare NRD. Adult respiratory distress syndrome. Am J Med Sci 1989; 298: 413-431.

3. Matthay MA. The adult respiratory distress syndrome, definition and prognosis. Clin Chest Med 1990; 11: 575580.

4. Tate RM, Repine JE. Neutrophils and the adult respiratory distress syndrome. Am Rev Respir Med 1983; 128: 552559.

5. Huber AR, Kunkel SL, Todd RF III, Weiss SJ. Regulation of transendothelial neutrophil migration by endogenous interleukin-8. Science 1991; 254: 99-102.

6. Mantovani A, Dejana E. Cytokines as communication signals between leukocytes and endothelial cells. Immunol Today 1989; 10: 370-375.

7. Baggiolini M, Dewald B, Moser B. Interleukin-8 and related chemotactic cytokines - $\mathrm{CXC}$ and $\mathrm{CC}$ chemokines. Adv Immunol 1994; 55: 97-179.

8. Strieter RM, Kunkel SL, Showell HL, et al. Endothelial cell gene expression of a neutrophil chemotatic factor by TNF- $\alpha$, LPS, and IL-1 $\beta$. Science 1989; 243: $1467-$ 1469.

9. Davis RJ. MAPKs: new JNK expand the group. Trends Biochem Sci 1994; 19: 470-473.

10. Han J, Lee JD, Bibbs L, Ulevitch RL. A MAP kinase targeted by endotoxin and hyperosmolarity in mammalian cells. Science 1994; 265: 808-811.

11. Rouse J, Cohen P, Trigon S, et al. A novel kinase cascade triggered by stress and heat shock that stimulates MAPKAP kinase-2 and phosphorylation of the small heat shock proteins. Cell 1994; 78: 1027-1034.

12. Raingeaud J, Gupta S, Rogers JS, et al. Pro-inflammatory cytokines and environmental stress cause p38 mitogenactivated protein kinase activation by dual phosphorylation on tyrosine and threonine. J Biol Chem 1995; 270: $7420-7426$.

13. Freshney N, Rawlinson L, Guesdon F, et al. Interleukin-1 activates a novel protein kinase cascade that results in the phosphorylation of hsp27. Cell 1994; 78: 1039-1049.

14. Beyaert R, Cuenda A, Berghe WV, et al. The p38/JNK mitogen-activated protein kinase pathway regulates interleukin-6 synthesis in response to tumor necrosis factor. EMBO J 1996; 15: 1914-1923.

15. Pandey P, Raingeaud J, Kaneki R, et al. Activation of p38 mitogen-activated protein kinase by c-abl-dependent and -independent mechanism. J Biol Chem 1996; 271: 23775-23779.

16. Morihuchi T, Toyoshima F, Gotoh Y, et al. Purification and identification of a major activator for p38 from osmotically shocked cells. Activation of mitogen-activated protein kinase kinase 6 by osmotic shock, tumor necrosis factor- $\alpha$, and $\mathrm{H}_{2} \mathrm{O}_{2}$. J Biol Chem 1996; 272: 2698126988.

17. Nick JA, Avdi AJ, Gerwins P, Johnson GL, Worthen GS. Activation of a p38 mitogen-activated protein kinase in 
human neutrophils by lipopolysaccharide. J Immunol 1996; 156: 4867-4875.

18. Foltz IN, Lee JC, Young PR, Schrader JW. Hemopietic growth factors with the exception of interleukin- 4 activate the p38 mitogen-activated protein kinase pathway. $J$ Biol Chem 1997; 272: 3296-3301.

19. Matsumoto K, Hashimoto S, Gon Y, Nakayama T, Horie T. Proinflammatory cytokine-induced and chemical mediator-induced IL-8 expression in human bronchial epithelial cells through p38 mitogen-activated protein kinase-dependent pathway. J Allergy Clin Immunol 1998; 101: 825-831.

20. Lee JC, Laydon JT, McDonnell PC, et al. A protein kinase involved in the regulation of inflammtory cytokine biosynthesis. Nature 1994; 372: 739-746.

21. Thomas PS. Hybridization of denatured RNA transferred or dotted to nitrocellulose paper. Methods Enzymol 1983; 100: 255-266.

22. Mukaida M, Shiroo M, Matsushima K. Genomic structure of the human monocyte-derived neutrophil chemotactic factor IL-8. J Immunol 1989; 143: 1366-1371.

23. Sluss HK, Barrett T, Derijard B, Davis RJ. Signal transduction by tumor necrosis factor mediated by JNK protein kinases. Mol Cell Biol 1994; 14: 8376-8384.

24. Cuenda A, Rouse J, Doza YN, et al. SB 203580 is a specific inhibitor of a MAP kinase homologue which is stimulated by cellular stress and interleukin-1. FEBS Lett 1995; 364: 229-233.

25. Ridley SH, Sarsfield SJ, Lee JC, et al. Actions of IL-1 are selectively controlled by p38 mitogen-activated protein kinase. J Immunol 1997; 158: 3165-3173.

26. Hyers TM, Tricomi AM, Dettenmeier PA, Fowler AA. Tumor necrosis factor levels in serum and bronchoalveolar lavage fluid of patients with the adult respiratory distress syndrome. Am Rev Respir Dis 1991; 144: 268-271.

27. Hinshaw LB, Tekamp-Olson P, Chang AC, et al. Survival of primates in $\mathrm{LD}_{100}$ septic shock following therapy with antibody to tumor necrosis factor (TNFa). Circ Shock 1990; 30: 279-292.

28. Ognibene FP, Martin SE, Parker MM, et al. Adult respiratory distress syndrome in patients with severe neutropenia. New Engl J Med 1986; 315: 547-551.

29. Horvath CJ, Ferro TJ, Jesmok G, Malik AB. Recombinant tumor necrosis factor increases pulmonary vascular permeability independent of neutrophils. Proc Natl Acad Sci USA 1988; 85: 9219-9223.

30. Miller EJ, Cohen AB, Nagao S, et al. Elevated levels of NAP-1/interleukin-8 are present in the airspace of patients with adult respiratory distress syndrome and are associated with increased mortality. Am Rev Respir Dis 1992; 146: 427-432. 